\title{
STABILITY AND ADAPTABILITY OF SORGHUM HYBRIDS ELUCIDATED WITH GENOTYPE-ENVIRONMENT INTERACTION BIPLOTS
}

\author{
Aamer MUMTAZ*, Dilbar HUSSAIN, Muhammad SAEED, Muhammad ARSHAD, \\ Muhammad Irfan YOUSAF \\ Maize and Millets Research Institute, Yusafwala, Sahiwal, PAKISTAN \\ *Corresponding author: aamer3002@gmail.com
}

Received: 14.04 .2018

\begin{abstract}
This study was conducted to compare the performance of ten sorghum hybrids at two locations (Maize and Millets Research Institute, Yusafwala, Sahiwal, MMRI) \& Sorghum Research Sub-Station, Dera Gazi Khan, D.G. Khan) for two consecutive years (2015 and 2016), i.e. in a total of four environments (MMRI-15, MMRI16, DG Khan-15 and DG Khan-16). The experiment was conducted in a Randomized Complete Block Design with a plot size of $4 \times 0.75 \times 2 \mathrm{~m}$. In all four environments the crop was sown in July and harvested in December. Five plants were selected randomly from each plot for data collection. The following ranges were determined in the investigated traits; grain yield $\left(2858.34-5266.33 \mathrm{~kg} \mathrm{ha}^{-1}\right)$, fodder yield $\left(28663-45667 \mathrm{~kg} \mathrm{ha}^{-1}\right)$, days to $50 \%$ anthesis (76-81 days) and Brix value (8.28 -18.42). Analysis of variance (ANOVA) estimates, generated by the biplot software were used for data interpretation. It was found that the influence of genotype, environment and $G \times E$ interaction was significant $(P<0.05)$ for all traits in all environments. The data for all traits except Brix value were useful for further study. For grain yield and fodder yield, hybrid YSH-95 was the most suitable due to its higher yield and better stability. Sorghum Research Sub-Station Dera Gazi Khan (DG Khan), a non-discriminating location, were considered suitable for generally adapted hybrids and Maize and Millets Research Institute, Yusafwala, Sahiwal (MMRI), a more discriminating location, were considered best for specifically adapted hybrids. The results of which-won-where biplots showed that Lasani was the best general hybrid at both locations, whereas YSH-95 was the best hybrid for the specific environmental conditions at MMRI.
\end{abstract}

Keywords: Brix value, correlation, Maize and Millets Research Institute, stalks weight,

\section{INTRODUCTION}

The livestock sector is increasing in Pakistan, and grew from 191.3 Million in 2016-2017 to $196.5 \%$ Million in 2017-2018. Similarly, chicken production also increased from 32.67 Million in 2016-2017 to 32.91 Million in 2017-2018. The availability of fodder and feed seed was 61140 metric tons, of which 13400 metric tons were imported in 2017-2018, at considerable expense. The availability of seed is increasing with the increase in livestock and chicken production. Despite its large milk (5790 tons) and meat (4262 tons) production, Pakistan is still ranked number 4 in milk production, number 9 in beef production and 28th in chicken production in all over all world (FAOSTAT, USDA, Govt. of Pakistan, 2017-18). The reasons for this situation are low quality fodder and limited feed availability. Because of low quality fodder and feed, animals reach puberty later, and the intercalving interval is shorter (Ali, 2011; Mumtaz et al., $2017 \mathrm{~b}$ ). This situation could be improved with increased milk and meat productivity per animal, and increased chicken production, and targets could be achieved by increasing milk, meat and chicken production up to $100 \%$ with good quality fodder and feed availability. However, land area used for fodder crops is decreasing steadily due to urbanization (Government of Pakistan, 2017-18). In addition, the unavailability of Trifolium alexandrinum L. (barseem) in lean periods (Dec, Jan and June, July) is a major factor in the limited availability of fodder (FAOSTAT).

The total area devoted to fodder production in Pakistan is 2.04 million hectares, and production is 51.92 metric tons. Sorghum (Sorghum bicolor) is cultivated in a total area of 0.255 million hectares, with a production of 148000 tons. Sorghum for fodder production thus accounts for $11.11 \%$ of the total area used for fodder crops, which is second largest area after barseem (43.54\%) (Pakistan Bureau of Statistics, 2017-18, Govt. of Pakistan, 2017-18). Because sorghum accounts for 15\%- 
$20 \%$ of all poultry feed (PARC, 2017), this crop appears to be the best target for tackling these issues given that sorghum grain is used as a feed and the stalks are used as fodder.

Sorghum is an important coarse grain crop in rain-fed and arid zones. This crop is important as a grain as well as a summer fodder crop in Pakistan (Bibi et al., 2010). It ranks fifth among important cereal crops worldwide, after wheat, rice, maize and barley (Ritter et al., 2007; Motlhaodi et al., 2014). Its grain is used as poultry feed, and its fodder is used for livestock. Its importance is increasing with the expansion of the poultry industry. It is also gaining importance as a source of starch for textile industries, and is also used in gum manufacture (FAOSTAT). It is a good source of carbohydrates and protein (Selle, 2011), and is palatable to animals due to its sweetness (Cifuentes et al., 2014; Mumtaz et al., 2017a).

Insect damage by stem borers is a major challenge to sorghum crop production. Sorghum is also affected to some extent by rootstalk disease, white fly, midges and mites. Hydrogen cyanide $(\mathrm{HCN})$ is present in sorghum fodders, which may be fatal to ruminants (Panhwar, 2005; Kumar and Devendra, 2010; PARC, 2017).

Genotype $\times$ environment interactions $(\mathrm{G} \times \mathrm{E})$ can be described as the different ranking of genotypes in different environmental conditions (Sayar et al., 2013). In their efforts to improve genotype selection, plant breeders have turned their attention to genotype $\times$ environment interactions $(\mathrm{G} \times \mathrm{E})$. In these models the superiority of a given variety can be estimated by relative ranking. However, evaluations based on $\mathrm{G} \times \mathrm{E}$ interactions in diverse environments can be challenging. Especially when the $\mathrm{G} \times \mathrm{E}$ interaction is significant $(\mathrm{P}<0.05)$, care must be taken to consider its cause, nature and implication (Kang and Gorman, 1989). Different stability analyses have been used for $\mathrm{G} \times \mathrm{E}$ interaction such as multivariate analysis (Westcoff, 1987), cluster analysis (Crossa et al. 1991), regression analysis (Guach, 1988) and the additive main effects and multiplicative interaction (AMMI) model (Guach, 1992). However, the most powerful technique is the $\mathrm{G} \times \mathrm{E}$ biplot technique owing to its visual presentation of interactions. The $\mathrm{G} \times \mathrm{E}$ biplot method with megaenvironment analysis has been used for many crops such as barley (Dehghani et al., 2006), maize (Fan et al., 2007), lentils (Sabaghnia et al., 2008), wheat (Mohammadi et al., 2009, Ilker et al., 2011) and grasspea (Sayar and Han, 2015).

The aim of this study was to compare the performance (adaptability and stability) of sorghum hybrids in two consecutive years at two locations, and to recommend the best sorghum hybrids and best environments for sorghum crops.

\section{MATERIALS AND METHODS}

Ten hybrids including three check cultivars (YS-16, YSS-98 and Lasani) were evaluated at two locations: the Maize and Millets Research Institute, Yusafwala, Sahiwal, Pakistan (MMRI) and Sorghum Research Sub-Station Dera Gazi Khan (DG Khan). Crops were grown in two consecutive years (2015 and 2016) and in three replications, for a total of four tested environments: MMRI-15, MMRI-16, DG Khan-15, DG Khan-16. In all four environments the crop was sown in July and harvested in December. The experiment was conducted in a randomized complete block design with three replications. Each plot size in the experiments was $6 \mathrm{~m}^{2}(4$ row numbers, $0.75 \mathrm{~m}$ row spacing, $2 \mathrm{~m}$ row length). The seed rate used was $8 \mathrm{Kg} \mathrm{ha}^{-1}$. All agronomic practices, i.e., irrigation, fertilizer application, pesticide application, hoeing and thinning, etc. were done at appropriate times. Five plants were selected randomly from each plot for data collection. The monthly climate data of MMRI and DG Khan is given in Table $1 \& 2$. There were continuous monsoon rains in July and August 2016 at MMRI which affected crop growth. A dry spell was observed in November, December in 2016 and 2017 in harvesting season of crop at DG Khan which was ideal for sorghum crop. The sorghum crop affected badly in November 2017 due to smog in the fields caused suffocation to the plants due to which plant growth of sorghum crop was affected badly in all Pakistan.

Table 1. Climate Data of Maize and Millets Research Institute, Yusafwala, Sahiwal, Pakistan

\begin{tabular}{|c|c|c|c|c|c|c|c|}
\hline \multirow{2}{*}{ Sr. } & \multirow{2}{*}{ Month } & \multicolumn{4}{|c|}{ Average temperature ${ }^{\circ} \mathrm{C}$} & \multirow{2}{*}{\multicolumn{2}{|c|}{ Rainfall (mm) }} \\
\hline & & \multicolumn{2}{|c|}{ Maximum } & \multicolumn{2}{|c|}{ Minimum } & & \\
\hline No. & & (2016) & (2017) & (2016) & (2017) & (2016) & (2017) \\
\hline 1 & July & 39.20 & 40.58 & 28.58 & 28.45 & 92.30 & 25.70 \\
\hline 2 & August & 39.09 & 39.67 & 27.09 & 27.93 & 75.00 & 9.00 \\
\hline 3 & September & 37.25 & 38.43 & 23.90 & 23.76 & 1.00 & 74.00 \\
\hline 4 & October & 34.71 & 37.52 & 18.55 & 19.77 & - & - \\
\hline 5 & November & 27.10 & 27.51 & 12.40 & 12.88 & - & 2.20 \\
\hline 6 & December & 26.39 & 27.45 & 9.00 & 7.21 & - & 7.60 \\
\hline \multicolumn{6}{|c|}{ Total Rainfall } & 186.3 & 118.5 \\
\hline
\end{tabular}


Table 2. Climate Data of Sorghum Research Sub-Station Dera Gazi Khan, Pakistan

\begin{tabular}{|c|c|c|c|c|c|c|c|}
\hline \multirow{3}{*}{$\begin{array}{l}\text { Sr. } \\
\text { No. }\end{array}$} & \multirow{3}{*}{ Month } & \multicolumn{4}{|c|}{ Average Temperature ${ }^{\circ} \mathrm{C}$} & & \\
\hline & & \multicolumn{2}{|c|}{ Maximum } & \multicolumn{2}{|c|}{ Minimum } & \multicolumn{2}{|c|}{ Rainfall (mm) } \\
\hline & & 2016 & 2017 & 2016 & 2017 & 2016 & 2017 \\
\hline 1 & July & 39.00 & 38.22 & 29.00 & 28.61 & 29.00 & 57.00 \\
\hline 2 & August & 37.00 & 37.70 & 28.00 & 28.41 & --- & --- \\
\hline 3 & September & 38.00 & 33.68 & 27.00 & 25.87 & --- & --- \\
\hline 4 & October & 37.80 & 35.38 & 26.33 & 20.67 & ---- & --- \\
\hline 5 & November & 28.50 & 23.48 & 13.90 & 12.80 & --- & --- \\
\hline 6 & December & 25.43 & 22.06 & 10.73 & 7.54 & --- & --- \\
\hline \multicolumn{6}{|c|}{ Total Rainfall } & 29.00 & 57.00 \\
\hline
\end{tabular}

Data were collected for the following traits: grain yield, fodder yield, days to $50 \%$ anthesis and Brix value. Brix value was estimated with the help of refractometer. The GGE biplot model was applied according to Yan and Kang (2003) and Sabaghnia et al. (2008) with the help of GEA-R software. The multi-location trial (MLT) data were analyzed without scaling ('Scaling 0 ' option) to generate tester-centered (centering 2) $\mathrm{G} \times \mathrm{E}$ biplots as suggested by $\mathrm{Yan}$ and Tinker (2006). For $\mathrm{G} \times \mathrm{E}$ genotype evaluation, $G \times E$ genotype-focused singular value partitioning $(\mathrm{SVP}=1)$ was used with the 'Mean versus stability' option of $G \times E$ biplot software, while for location evaluation, environment-focused singular value partitioning (SVP = 2) was used (Yan 2001) with the 'Relation among testers' option. The 'Which-won-where' option was used to identify which genotype was the winner in a given environment, and to identify megaenvironments. Analysis of variance (ANOVA) estimates generated by the biplot software were used for interpretation.

\section{RESULTS AND DISCUSSION}

\section{Statistical significance and proportion of variation}

The results of ANOVA and the proportions of variance accounted for by $G \times$ E genotype $(G)$, environment $(E)$ and interaction $(G \times E)$ are presented in Table 3. The effects of $\mathrm{G}, \mathrm{E}$ and $\mathrm{G} \times \mathrm{E}$ were highly significant $(\mathrm{P}<0.01)$ for all traits except $G \times E$ and Brix value, which were significant $(\mathrm{P}<0.05)$ to a lesser degree. Environment was the largest source of variation in grain yield. For grain yield the environment contributed $37.25 \%$ of the variation, compared to $\mathrm{G}$ genotype (33.22\%) and $\mathrm{G} \times \mathrm{E}$ interaction $(29.52 \%)$. For days to $50 \%$ flowering, the contribution of $\mathrm{G} \times \mathrm{E}$ was $53.44 \%$ versus $\mathrm{G}$ genotype $(21.96 \%)$ and environment (24.59\%). For fodder yield, the contribution of $\mathrm{G} \times \mathrm{E}$ was $59.15 \%$ versus $\mathrm{G}$ genotype $(26.40 \%)$ and environment (14.45\%). For Brix value, the contribution of G genotype was $98.41 \%$ versus environment $(1.01 \%)$ and $\mathrm{G} \times \mathrm{E}(0.57 \%)$ (Table 3$)$.

Table 3. ANOVA and proportion of variation in $\mathrm{G}, \mathrm{E}$ and $\mathrm{G} \times \mathrm{E}$

\begin{tabular}{|c|c|c|c|c|}
\hline Trait & & $\mathbf{G}$ & $\mathbf{E}$ & $\mathbf{G} \times \mathbf{E}$ \\
\hline Grain yield & MS & $6206744 * *$ & $20876852 * *$ & $1838546^{* *}$ \\
\hline$(\mathbf{K g})$ & Proportion of $\mathrm{G}+\mathrm{E}+\mathrm{G} \times \mathrm{E}$ & 33.22431 & 37.25083 & 29.52486 \\
\hline Fodder yield & $\mathrm{MS}$ & $257385289 * *$ & $422549916^{* *}$ & $192217418 * *$ \\
\hline$(\mathbf{K g})$ & Proportion of $G+E+G \times E$ & 26.40154 & 14.44782 & 59.15065 \\
\hline \multirow{2}{*}{ Days to $50 \%$ flowering } & MS & $54.92685^{* *}$ & $184.5417 * *$ & $44.56636 * *$ \\
\hline & Proportion of $\mathrm{G}+\mathrm{E}+\mathrm{G} \times \mathrm{E}$ & 21.95846 & $24.5918 *$ & 53.44974 \\
\hline Brix value & MS & $243.0069 * *$ & $7.53897 * *$ & $0.4694^{*}$ \\
\hline$(\%)$ & Proportion of $G+E+G \times E$ & 98.41201 & 1.0177 & 0.57029 \\
\hline
\end{tabular}

G, Genotype; E, Environment; G $\times$ E, Genotype $\times$ Environment interaction; **Highly significant $(\mathrm{P}<0.01) ;{ }^{*}$ Significant $(\mathrm{P}<0.05)$

In accordance with our research findings, many researchers in various crops reported that effect of environment was much greater than the effects of genotype and $\mathrm{G} \times \mathrm{E}$ in grain yield trait (Gauch and Zobel, 1997; Dehghani et al., 2006; Kaya et al., 2006; Kendal and Sayar, 2016). Additionally, in their study of peanut strains, Putto et al. (2008) observed that environment accounted for $15 \%-46 \%$. They found a very low contribution by $\mathrm{G} \times \mathrm{E}(4 \%-5 \%)$. In another study of sorghum, Rakshit et al. (2012) found that location accounted for a large proportion $(59.3 \%-89.9 \%)$ of variation, whereas $\mathrm{G} \times \mathrm{E}$ genotype explained a relatively low proportion (3.9\%-16.7\%). In maize, Munawar et. al. (2013) found that environment explained $79.22 \%$ of the variation, whereas $\mathrm{G} \times \mathrm{E}$ genotype explained only $9.52 \%$. In comparison to these findings, we found that environment accounted for $1.01 \%-37 \%$ of the variation, $\mathrm{G} \times \mathrm{E}$ genotype for $33.22 \%-98.41 \%$, and $\mathrm{G} \times \mathrm{E}$ interaction for $0.57 \%-59.15 \%$. Our results for grain yield and Brix value are broadly similar to the findings reported by Putto et al., 2008. In addition, the larger contribution of $\mathrm{G} \times \mathrm{E}$ interaction to variations in fodder yield and days to 50\% flowering is consistent with Rakshit et al. (2012). 


\section{$G \times$ E genotypic stability}

Performance and stability of $\mathrm{G} \times \mathrm{E}$ genotypes are characterized as principal components (PCs) and presented graphically in Figures 1 to 4 (Yan and Tinker, 2006). If the total variability explained by the first two PCs is more than $60 \%$ and the variability explained by $G$ $\times \mathrm{E}$ is more than $10 \%$, then it is possible to elaborate the information from the $\mathrm{G} \times \mathrm{E}$ data (Yang et al. 2009; Yan et al. 2010) with the average environment coordination (AEC) method. We generated tester-centered $\mathrm{G}+\mathrm{G} \times \mathrm{E}$ biplots with no scaling for grain yield, fodder yield, days to $50 \%$ flowering and Brix value. The first two PCs for grain yield represented $85.06 \%$ of the variation; for fodder yield they accounted for $84.18 \%$ of the variation; for days to $50 \%$ flowering they accounted for $96.2 \%$, and for Brix value they explained $99.95 \%$ of the variation. It is clear from above results that our $\mathrm{G} \times \mathrm{E}$ data for all traits except Brix value can be used for further elaboration, given that the contribution of $\mathrm{G} \times \mathrm{E}$ to Brix value is only $0.75 \%$ (less than $10 \%$ ).

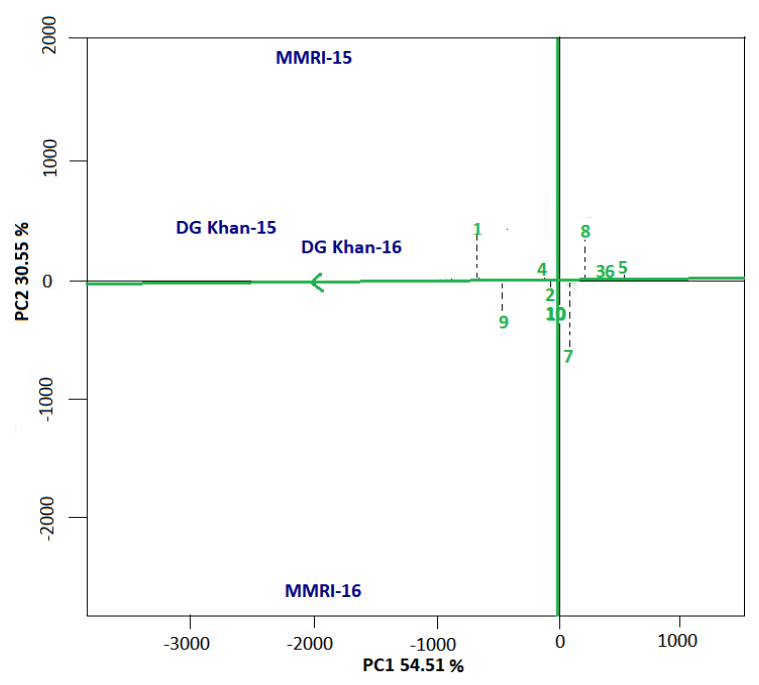

Figure 1. GGE biplots of the combined analysis for grain yield

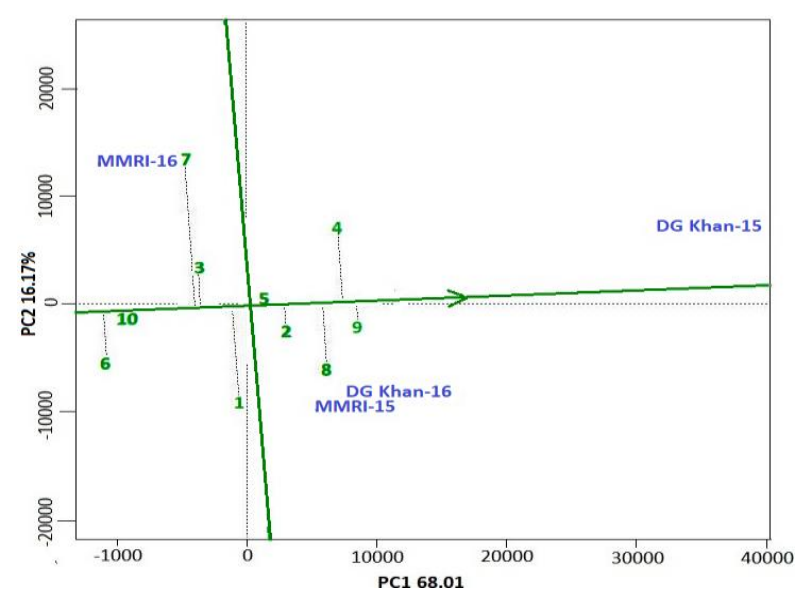

Figure 2 GGE biplots of the combined analysis for fodder yield

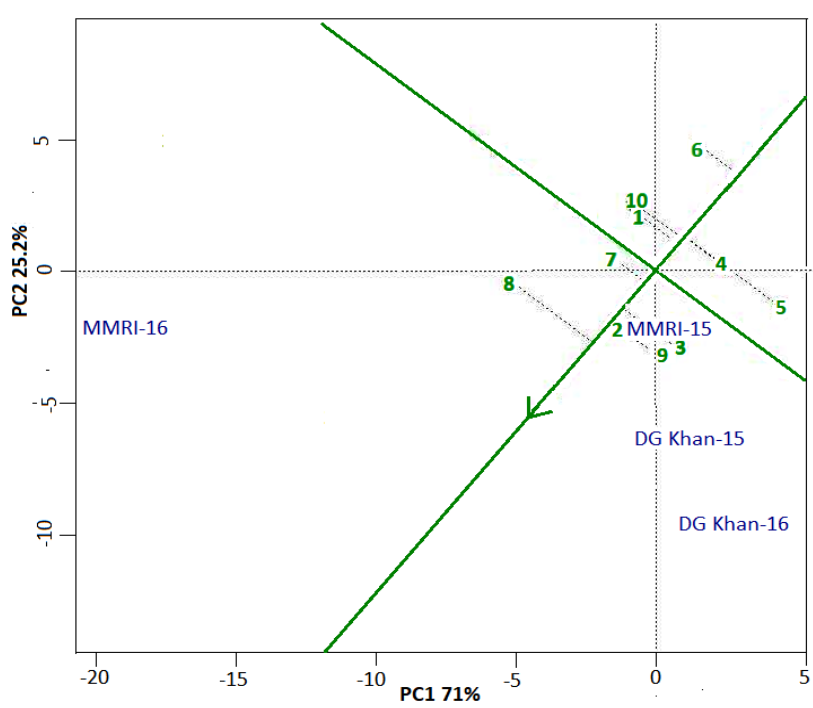

Figure 3. GGE biplots of the combined analysis for days to $50 \%$ flowering

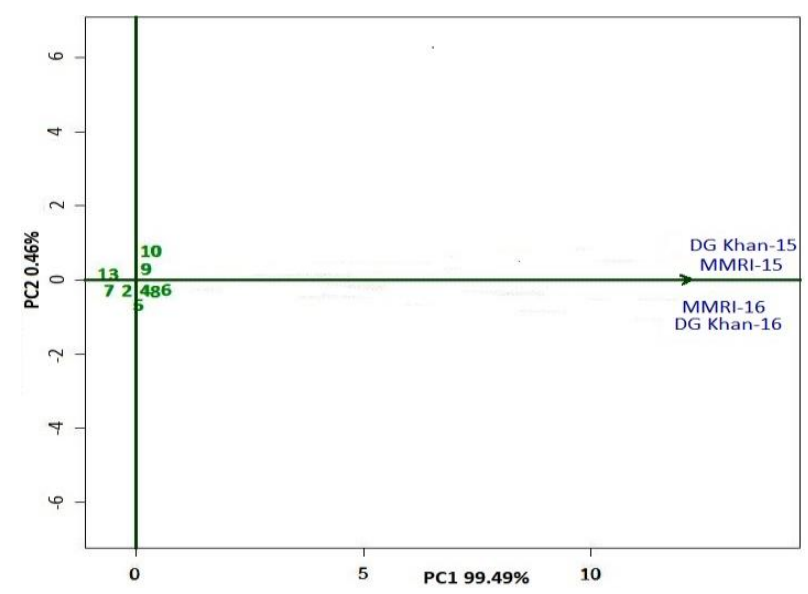

Figure 4 GGE biplots of the combined analysis for Brix value

The vertical line with a single arrowhead passing through the origin is called the AEC abscissa. The $\mathrm{G} \times \mathrm{E}$ genotypes closest to the arrowheads on the abscissa are the ones that come closest to the ideal performance. The average environments have near-average PC1 and PC2 scores; in other words, the environmental situation can be considered normal (Yan, 2001). The perpendicular line which passes through the origin is referred to as the AEC ordinate. The shorter the projection of a cultivar on this line, the more stable the cultivar is likely to be (Kaya et al., 2006).

The grain yield was observed in a range of $2858.34 \mathrm{Kg}$ $\mathrm{ha}^{-1}$ to $5266.33 \mathrm{Kg} \mathrm{ha}^{-1}$. These results are similar with the findings of Rakhsit et al. (2012) in India (2180 Kg ha-1 to $\left.4234 \mathrm{Kg} \mathrm{ha}^{-1}\right)$ and Mumtaz et al. (2018) in Pakistan (2562 $\mathrm{Kg} \mathrm{ha}^{-1}$ to $5190 \mathrm{Kg} \mathrm{ha}^{-1}$ ). Hybrid 1 (Lasani) showed the highest grain yield, followed by hybrid 9 (YSH-95). However, YSH-95 was more stable than Lasani, as shown by its shorter AEC ordinate compared to Lasani. The most stable hybrids were 5 (YSH-121) and 6 (YSH-1227); however, their yields were lower than other hybrids. Hybrids 4 (YSH-120) and 2 (YS-16) also showed good stability but their yields were near the middle of the range 
for all hybrids (Fig. 1 and Table 4). For fodder yield, they range of $28663 \mathrm{Kg} \mathrm{ha}^{-1}$ to $45667 \mathrm{Kg} \mathrm{ha}^{-1}$ was observed. Similar findings were observed by Dhar et al., $2005\left(29600 \mathrm{Kg} \mathrm{ha}^{-1}\right.$ to $\left.39700 \mathrm{Kg} \mathrm{ha}^{-1}\right)$ in India while observed the very less fodder yield in India $\left(9405 \mathrm{Kg} \mathrm{ha}^{-1}\right.$ to $18649 \mathrm{Kg} \mathrm{ha}^{-1}$ ) while Ayub et al., 2004 observed very high range fodder yield (40920 $\mathrm{Kg} \mathrm{ha}^{-1}-68090 \mathrm{Kg} \mathrm{ha}^{-1}$ ) in Pakistan. The highest yielded was hybrid 9 (YSH-95) followed by hybrid 4 (YSH-120). Moreover, YSH-95 was more stable in terms of fodder yield. The most stable hybrids were 10 (YSS-98) and 5 (YSH-121), but YSS-98 had the lowest yield, and YSH-121 was a medium yielder (Fig. 2). The days to $50 \%$ flowering was observed in range of (76-81). Mumtaz et al., 2018 in Pakistan (72-82) and Rakhsit et al., 2012 in India (59-77) observed similar findings. Hybrid 8 (YSH-75) had the longest period to $50 \%$ flowering followed by hybrid 9 (YSH-95). Hybrid 6 (YSH-1227) had the shortest period to $50 \%$ flowering, and for hybrid 7 (YSH-61) this period was of average duration. YSH-95, YSH-1227 and YSH-61 were more stable than other hybrids (Fig. 3).

Table 4. Mean time to $50 \%$ flowering, Brix value, fodder yield and grain yield of sorghum hybrids per year and per location

\begin{tabular}{|c|c|c|c|c|c|c|c|c|c|c|c|c|}
\hline \multirow[t]{2}{*}{$\begin{array}{l}\text { Genotype } \\
\text { /Year }\end{array}$} & \multicolumn{3}{|c|}{ Grain yield $\left(\mathrm{Kg} \mathrm{ha}^{-1}\right)$} & \multicolumn{3}{|c|}{ Days to $50 \%$ flowering } & \multicolumn{3}{|c|}{ Brix value $(\%)$} & \multicolumn{3}{|c|}{ Fodder yield $\left(\mathrm{Kg} \mathrm{ha}^{-1}\right)$} \\
\hline & 2015 & 2016 & Mean & 2015 & 2016 & Mean & 2015 & 2016 & Mean & 2015 & 2016 & Mean. \\
\hline Lasani $(\subset$ & 5793.76 & 4738.90 & 5266.33 & 75.67 & 78.25 & 76.96 & 8.50 & 8.06 & 8.28 & 37257.02 & 36979.24 & 37118.13 \\
\hline YS-16 @ & 4445.15 & 3584.73 & 4014.94 & 77.83 & 81.33 & 79.58 & 11.64 & 12.23 & 11.94 & 40972.30 & 39965.36 & 40468.83 \\
\hline YSH-118 & 3620.84 & 2943.06 & 3281.95 & 79.33 & 80.75 & 80.04 & 9.54 & 8.72 & 9.13 & 37882.02 & 37708.41 & 37795.22 \\
\hline YSH-120 & 4614.59 & 3670.15 & 4142.37 & 78.00 & 78.25 & 78.13 & 16.54 & 17.48 & 17.01 & 48750.10 & 42048.70 & 45399.40 \\
\hline YSH-121 & 3322.92 & 2393.76 & 2858.34 & 79.08 & 78.33 & 78.71 & 13.65 & 13.84 & 13.75 & 40416.75 & 33680.62 & 37048.69 \\
\hline YSH-1227 & 3211.12 & 2955.56 & 3083.34 & 76.33 & 75.67 & 76.00 & 17.67 & 19.17 & 18.42 & 26319.50 & 31007.01 & 28663.25 \\
\hline YSH-61 & 3300.70 & 3265.28 & 3282.99 & 78.92 & 80.50 & 79.71 & 9.09 & 8.26 & 8.68 & 33541.73 & 35069.51 & 34305.62 \\
\hline YSH-75 & 3797.92 & 3077.78 & 3437.85 & 78.75 & 82.58 & 80.67 & 16.82 & 19.04 & 17.93 & 43437.59 & 39861.19 & 41649.39 \\
\hline YSH-95 & 4444.45 & 4513.82 & 4479.14 & 80.00 & 81.58 & 80.79 & 16.03 & 16.51 & 16.27 & 47083.43 & 44270.92 & 45677.18 \\
\hline YSS-98 @ & 3979.17 & 3546.54 & 3762.86 & 76.25 & 78.00 & 77.13 & 17.88 & 17.53 & 17.71 & 31909.79 & 30173.67 & 31041.73 \\
\hline $\begin{array}{l}\text { Genotype } \\
\text { /Location }\end{array}$ & MMRI & $\begin{array}{l}\text { DG } \\
\text { Khan }\end{array}$ & Mean & MMRI & $\begin{array}{l}\text { DG } \\
\text { Khan }\end{array}$ & Mean & MMRI & $\begin{array}{l}\text { DG } \\
\text { Khan }\end{array}$ & Mean & MMRI & $\begin{array}{l}\text { DG } \\
\text { Khan }\end{array}$ & Mean \\
\hline Lasani & 4678.48 & 5854.18 & 5266.33 & 79.08 & 74.83 & 76.96 & 8.13 & 8.43 & 8.28 & 37465.35 & 36770.91 & 37118.13 \\
\hline YS-16 & 3502.09 & 4527.79 & 4014.94 & 80.67 & 78.50 & 79.58 & 11.40 & 12.47 & 11.94 & 36527.85 & 44409.81 & 40468.83 \\
\hline YSH-118 & 3390.28 & 3173.62 & 3281.95 & 79.25 & 80.83 & 80.04 & 9.28 & 8.98 & 9.13 & 41007.03 & 34583.40 & 37795.22 \\
\hline YSH-120 & 3368.06 & 4916.68 & 4142.37 & 79.08 & 77.17 & 78.13 & 15.99 & 18.03 & 17.01 & 39375.08 & 51423.71 & 45399.40 \\
\hline YSH-121 & 2383.34 & 3333.34 & 2858.34 & 78.42 & 79.00 & 78.71 & 13.23 & 14.27 & 13.75 & 33263.96 & 40833.42 & 37048.69 \\
\hline YSH-1227 & 2958.34 & 3208.34 & 3083.34 & 78.50 & 73.50 & 76.00 & 17.15 & 19.68 & 18.42 & 35000.07 & 22326.43 & 28663.25 \\
\hline YSH-61 & 2565.98 & 4000.01 & 3282.99 & 82.92 & 76.50 & 79.71 & 8.73 & 8.62 & 8.68 & 32638.95 & 35972.29 & 34305.62 \\
\hline YSH-75 & 2722.92 & 4152.79 & 3437.85 & 84.75 & 76.58 & 80.67 & 16.46 & 19.40 & 17.93 & 34132.01 & 49166.77 & 41649.39 \\
\hline YSH-95 & 3680.48 & 5277.79 & 4479.14 & 81.33 & 80.25 & 80.79 & 15.28 & 17.27 & 16.27 & 38680.63 & 52673.72 & 45677.18 \\
\hline YSS-98 & 3838.20 & 3687.51 & 3762.86 & 79.75 & 74.50 & 77.13 & 16.96 & 18.45 & 17.71 & 37882.02 & 24201.44 & 31041.73 \\
\hline
\end{tabular}

MMRI, Maize and Millets Research Institute, Yusafwala, Sahiwal; DG Khan, Sorghum Research Sub-Station Dera Gazi Khan

The sugar content of juice extracted from stalks of the sorghum defined as Brix value $(\%)$. The results for Brix value were confirmed in Figure 4 . There was a large variation in brix value (8.28 to 18.42$)$ due to diverse germplasm especially with respect to parental lines, some are from ICRISAT India, and some are from Pakistan. A large variation in brix value was also observed by Mumtaz et al., 2018 in Pakistan (3.41-18.12). The greatest proportion of variation in Brix value is explained by genotype, i.e. almost all variation is explained by the first PC (99.94\%). As a result, the $\mathrm{G} \times \mathrm{E}$ biplot is ambiguous and cannot be used for further analysis (Fig. 4). The results show that YSH-95 was the highest yielded, and was also more stable in terms of fodder yield and grain yield. For days to 50\% flowering, hybrid YSH-95 had the second longest flowering period but was stable, as shown by its location nearest to AEC ordinate. Genotype stability was also determined by Dehghani et al. (2006) in barely, Kaya et al. (2006) in wheat, Sabaghnia et al. (2008) in lentil, Dehghani et al. (2008) rapeseed, Khalil et al. (2011) in maize, Rakhsit et al. (2012) in sorghum, Munawar et al. (2013) in maize and Kendal et al. (2016) in triticale. Rakshit et al. (2012) reported that the first two PCs accounted for $70 \%$ of the cumulative variation in four traits. Rakshit et al. (2012) found that $\mathrm{G} \times \mathrm{E}$ interaction explained $10 \%$ of the total variation for all traits.

\section{Environmental evaluation (ideal and discriminating environments)}

To better understand the capacity for adaptation of different $G \times E$ genotypes and further study the environments compared here, we ranked the four environments on the basis of grain yield, fodder yield, days to $50 \%$ flowering and Brix value. The relationships among environments can be determined as the angles between their vectors, and their correlations can be predicted from the cosine of the angles between the vectors (Yan and Tinker, 2006). For grain yield, DG Khan-15 and DG Khan-16 were highly correlated, whereas MMRI-15 and MMRI-16 were divergent. We identified two mega-environments; the first comprised DG Khan-15, DG Khan-16 and MMRI-15 while the second included only MMRI-16 (Fig. 5). Similar patterns were observed for fodder yield and days to $50 \%$ flowering; however, fodder yield values correlated more closely between MMRI-15 and DG Khan-16 than between either of these environments and DG Khan-15 (Figs. 6, 7). 


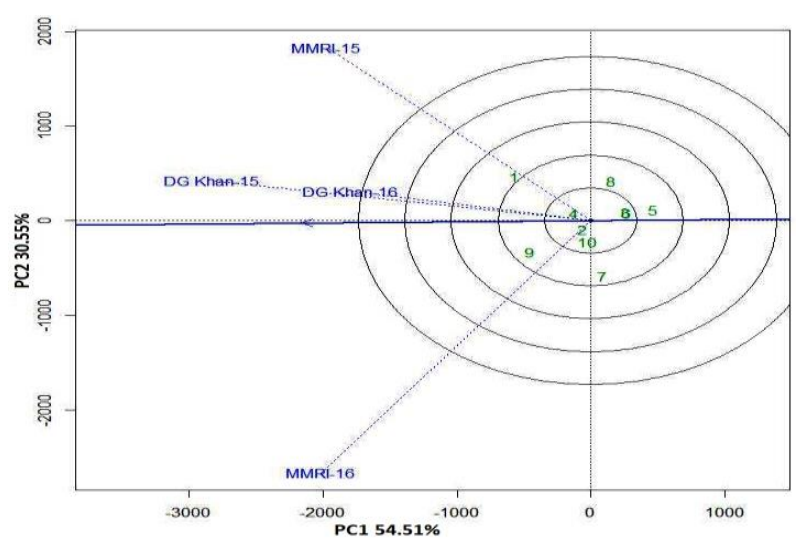

Figure 5 Relation among environments for grain yield

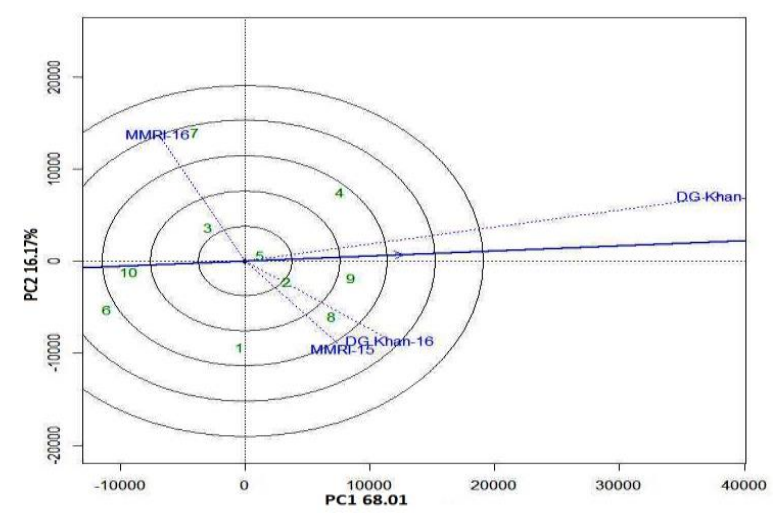

Figure 6. Relation among environments for fodder yield

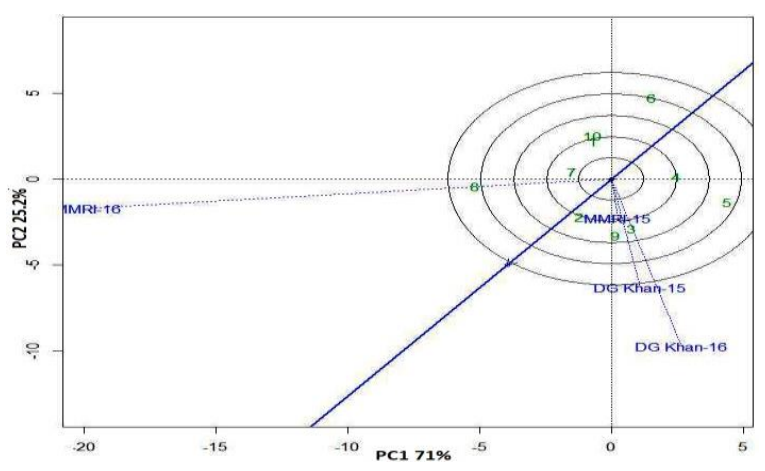

Figure 7 Relation among environments for days to $50 \%$ flowering

The discriminating ability of environments can be predicted from their projections across concentric circles. For grain yield, MMRI-15 and MMRI-16 were more discriminating than DG-Khan-15 or DG-Khan-16. This result indicates that DG Khan-15 came closest to the ideal environment, followed by DG-Khan 16. DG Khan-15 thus proved to be an ideal environment for generally adapted sorghum hybrids (Fig. 5). On the other hand, MMRI-15 and MMRI-16 were the most discriminating environments for specifically adapted sorghum hybrids. This result is consistent with the data shown in Table 4. Grain yield was highest at the two DG Khan environments for all hybrids except YSS-98. Thus hybrid Lasani should be recommended for cultivation in all four environments compared here, while YSH-95 should be recommend for cultivation at MMRI.

For Brix value, the results were ambiguous and did not lend themselves to elaboration (Fig. 8).

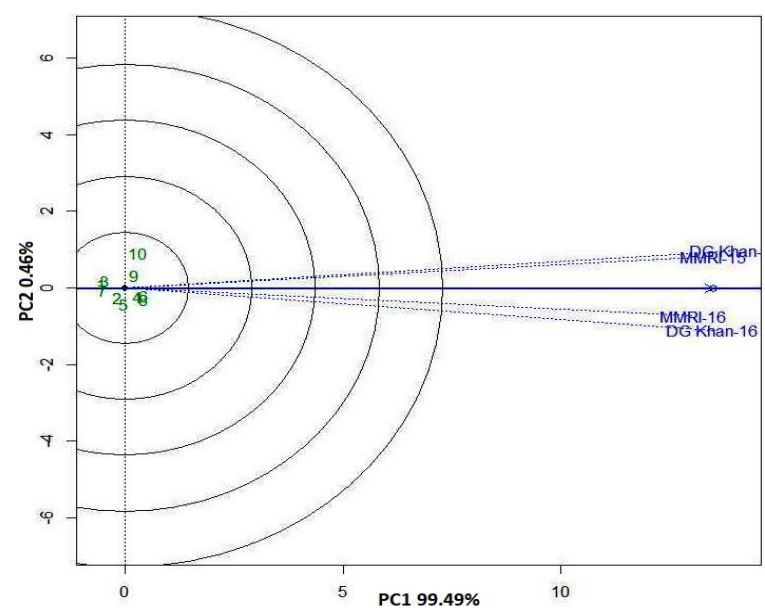

Figure 8 Relation among environments for Brix value

Our results suggest that to evaluate different hybrids, trials should be conducted at MMRI for two consecutive years in order to control for fluctuations in environmental conditions. In contrast, the results of sorghum hybrid trials at DG Khan for one year can be considered reliable. Environmental evaluations with the method used here were also reported by Khali et al. (2011), Mitrovic et al. (2012), Rakhsit et al. (2012) and Munawar et al. (2013).

\section{Ideal genotype}

Given the most important trait is grain yield, we ranked grain yield for all $\mathrm{G} \times \mathrm{E}$ genotypes with reference to the ideal $\mathrm{G} \times \mathrm{E}$ genotype in Figure 9. The ideal genotype can be identified by its position nearest the center of the concentric circles, and genotypes closest to the ideal genotype can be considered the most desirable. This analysis extends the information that can be deduced from the mean values summarized in Table 4. Figure 9 shows that hybrid 9 (YSH-95) was closest to the ideal $\mathrm{G} \times$ E genotype, followed by hybrid 1 (Lasani). Hybrids YSH95 (4604.05 Kg ha ${ }^{-1}$ ) and Lasani (4314.59 $\mathrm{Kg} \mathrm{ha}^{-1}$ ) had the highest grain yields (Table 4). Among earlier reports that identified ideal genotypes with this method are those by Dehghani et al. (2006), Kaya et al. (2006), Sabaghnia et al. (2008), Dehghani et al. (2008), Khalil et al. (2011), Mitrovic et al. (2012), Rakhsit et al. (2012) and Munawar et al. (2013).

\section{Mega-environment identification with which-won-where analysis}

The which-won-where graphs show polygons to illustrate the performance of $\mathrm{G} \times \mathrm{E}$ genotypes in different environments in order to summarize multi-environment data. Equality lines are drawn perpendicular to the origin of the biplot through the sides of the polygon (Yan, 2001). $\mathrm{G} \times \mathrm{E}$ genotypes are identified as suitable or less desirable according to their positions at the polygon vertices. The $G$ 
$\times$ E genotype positioned at the vertex falling within the sectors is considered the best (Yan, 2002; Yan and tinker 2006). Which-won-where biplots for grain yield, fodder yield, days to $50 \%$ flowering and Brix value are presented in Figures 10 to 13. These results show that only the grain yield biplot provides a clear picture, whereas the biplots for fodder yield, Brix value and days to $50 \%$ flowering are much less informative. Accordingly, we discuss here only the grain yield biplot.

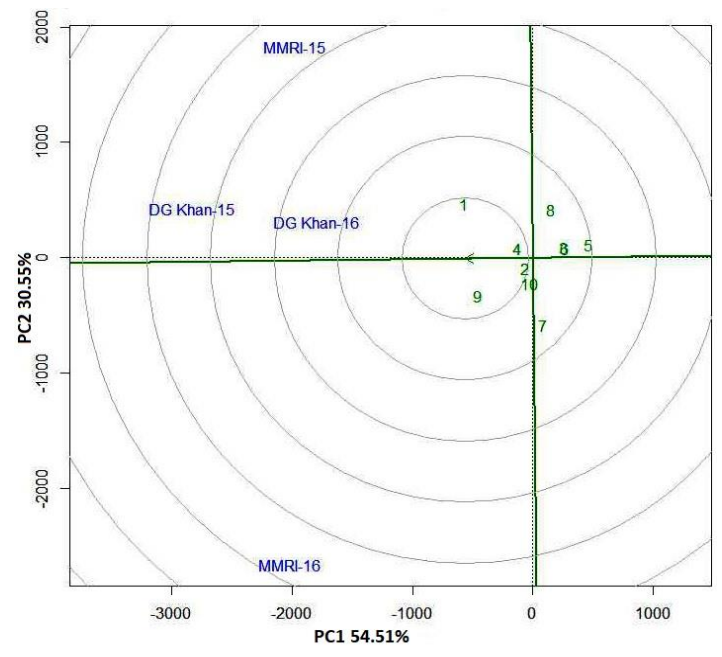

Figure 9 Ranking of ideal genotypes

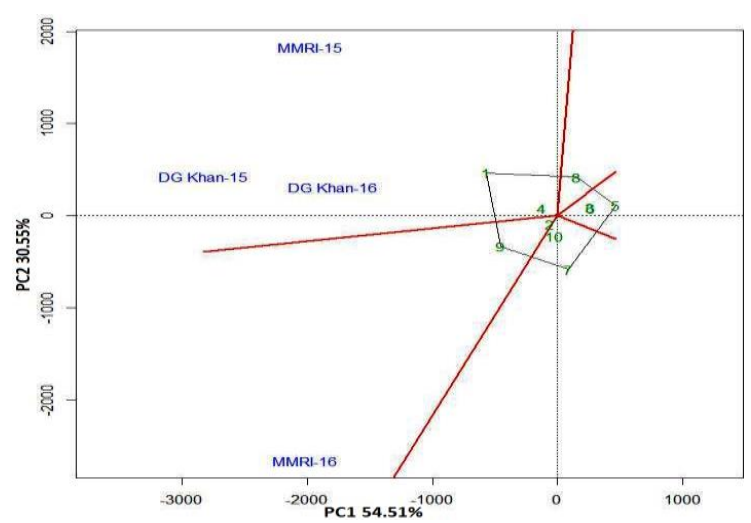

Figure 10 Which-won-where analysis of the genotypes for grain yield

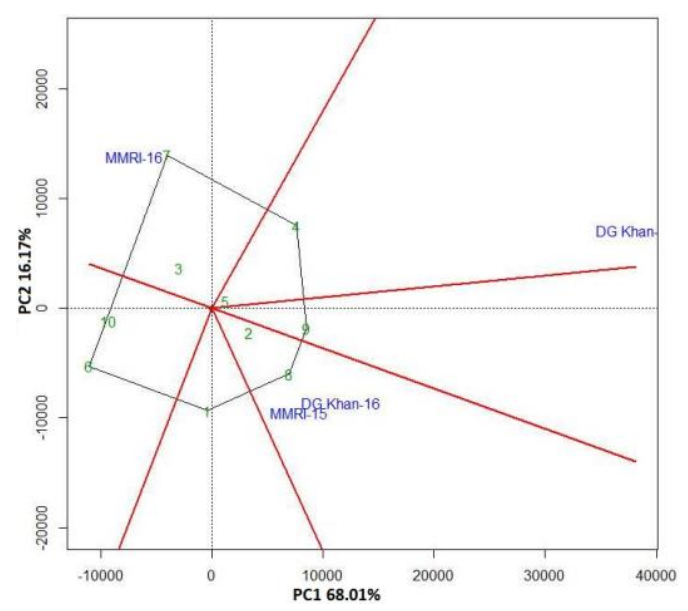

Figure 11 Which-won-where analysis of the genotypes for fodder yield

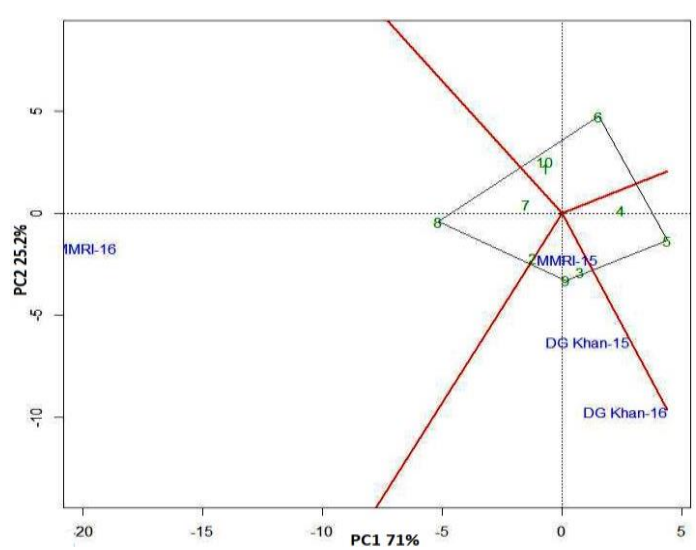

Figure 12 Which-won-where analysis of the genotypes for days to $50 \%$ flowering

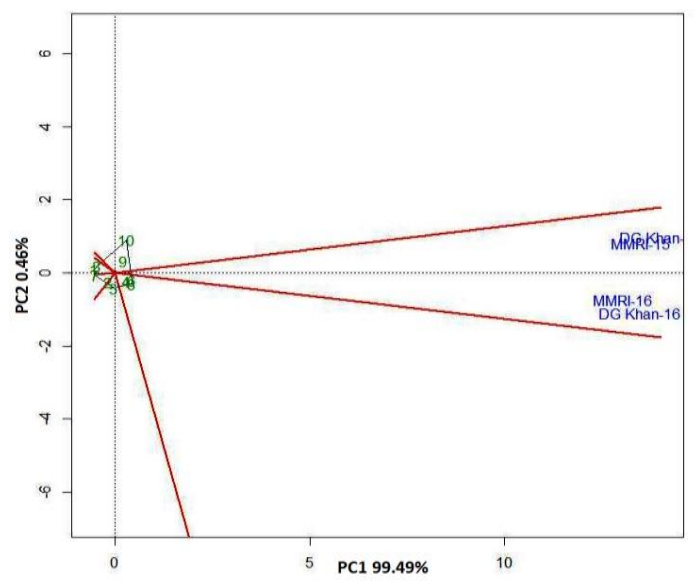

Figure 13 Which-won-where analysis of the genotypes for Brix value 
The polygon in Figure 10 has five $\mathrm{G} \times \mathrm{E}$ genotypes at the vertices. Hybrid 9 (YSH-95) performed best at MMRI16, and hybrid 1 (Lasani) performed best at DG Khan-15, DG Khan-16 and MMRI-15. The equality lines divide the biplot into five sectors, and indicate that the testing locations can be divided into two mega-environments. One contains MMRI-15, DG Khan-15 and DG Khan-16, with Lasani as best performing hybrid, while the other contains MMRI-16 with YSH-95 as the best performing hybrid. These results confirm the results of our environmental evaluation above. A similar approach to mega-environment identification and specific adaptation was also used by (Gauch and Zobel (1997), Yan et al. (2000), Yan and Tinker (2006), Putto et al. (2008), Rao et al. (2011), Rakshit et al. (2012), Khalil et al. (2011), Munawar et al. (2013) and Mitrovic et al. (2013).

\section{CONCLUSION}

Ten hybrids including three checks were evaluated in 2015 and 2016 at four environments: MMRI-15, MMRI16, DG Khan-15, DG Khan-16. Four traits were considered: grain yield, fodder yield, days to $50 \%$ flowering and Brix value. Our results showed that $G, E$ and $\mathrm{G} \times \mathrm{E}$ were significant $(\mathrm{P}<0.05)$ for all traits, and that the data for all traits except Brix value can be used for further study. The contribution of $\mathrm{G} \times \mathrm{E}$ to Brix value was only $0.75 \%$ (less than $10 \%$ ). According to grain yield and fodder yield, hybrid YSH-95 was the most suitable due to its high yield and greater stability. This hybrid has the second longest time to $50 \%$ flowering yet was also stable. Hybrid YSH-1227 had the shortest time to 50\% flowering but was a poor yielder. The DG Khan location was nondiscriminating and was thus best for generally adapted hybrids, whereas for specific selected hybrids, MMRI was a more discriminating location. Our results also suggest that trials designed to evaluate different hybrids should be conducted at MMRI for two consecutive years to control for environmental fluctuations, whereas trials run for a single year at the DG Khan location can be assumed to produced reliable data. From our which-won-where biplots we conclude that Lasani is the best general hybrid for all four environments, whereas hybrid YSH-95 is the best hybrid for the specific environment at the Maize and Millets Research Institute, Yusafwala, Sahiwal.

\section{ACKNOWLEDGMENTS}

The authors are grateful to field staff of the Maize and Millet Research Institute, Yusafwala for their efforts. The authors thank Dr. Abid Mehmood, Director General Agri. Research (Punjab) and the Government of Punjab for their support, and K. Shashok (AuthorAID in the Eastern Mediterranean) for improving the use of English in the manuscript. The authors are grateful to Punjab Agriculture Research Board, Punjab, Pakistan for their financial support for this publication.

\section{LITERATURE CITED}

Ali, S. 2011. Economic losses due to delayed conception in dairy animals of small farmers in district Gujranwala. M.Sc. (Hons) Thesis, Department of Agricultural Economics, Faculty of Agricultural Economics \& Rural Sociology,
University of Agriculture, Faisalabad, Pakistan. icdd.uaf.edu.pk/Publications/011.pdf (Accessed April 14, 2018).

Ayub, M., A. Tanveer, M.A. Nadeem and S.M.A. Shah. 2004. Studies on the Fodder Yield and Quality of Sorghum Grown Alone and in Mixture with Ricebean. Pak. J. Life Soc. Sci. 2(1): 46-48.

Bibi, A., H.A. Sadaqat, H.M. Akram and M.I. Mohammed. 2010. Physiological markers for screening sorghum (Sorghum bicolor) germplasm under water stress condition. Intl. J. Agri. Bio. 12(3):451-455.

Cifuentes, R., R. Bressani and C. Rolz. 2014. The potential of sweet sorghum as a source of ethanol and protein. Energy for Sustain. Develop. 21:13-19.

Crossa, J., P.N. Fox, W.H. Pfeiffer, S. Rajaram and H.G. Gauch. 1991. AMMI adjustment for statistical analysis of an international wheat yield trial. Theo. Applied Genet. 81:2737.

Dehghani, H., A. Ebadi and A. Yousefi. 2006. Biplot analysis of genotype by environment interaction for barley yield in Iran. Agron. J. 98:388-393.

Dehghani, H., H. Omidi and N. Sabaghnia. 2008. Graphic analysis of trait relations of rapeseed using the biplot method. Agron. J. 100:1443-1449.

Dhar, S., S.D. Gupta, S.N. Tripathi and S.K. Rai. 2005. Production potential of fodder sorghum (Sorghum bicolor) varieties under different nitrogen levells and sowing dates. Indian J. Agric. Sci. 75 (9): 572-575.

Fan, X.M., M.S. Kang, H. Chen, Y. Zhang, J. Tan and C. Xu. 2007. Yield stability of maize hybrids evaluated in multienvironment trials in Yunnan, China. Agron. J. 99:220-228.

FAOSTAT. 2017. Food and Agriculture Organization, United States. http://www.fao.org/faostat/en/\#home.

Gauch, H.G. 1988. Model selection and validation for yield trials with interaction. Biometr. 44:705-715.

Gauch, H.G., and R.W. Zobel. 1997. Identifying megaenvironment and targeting genotypes. Crop Sci. 37:381-385.

Gauch, H.G. 1992. Statistical analysis of regional yield trials: AMMI analysis of factorial designs. Elsevier, Amsterdam, The Netherlands. pp. 53-110.

Government of Pakistan. 2016-17. Economic Survey of Pakistan. Finance Division, Economic Advisory Wing, Islamabad. Pakistan.

Ilker, E., H. Geren, R. Unsal, I. Sevin, F. Aykut tonk and M. Tosun. 2011. AMMI-Biplot analysis of yield performances of bread wheat cultivars grown at different locations. Turk. J. Field Crops, 16(1): 64-68.

Kang, M.S., and D.P. Gorman. 1989. G × E Genotype $\times$ environment interaction in maize. Agron. J. 81(4):662-664.

Kaya, Y.M., M. Akcurra and S. Taner. 2006. GGE-biplot analysis of multi-environment yield trials in bread wheat. Turkish J. Agri. For. 30:325-337.

Kendal, E. and M.S. Sayar. 2016. The stability of some spring triticale genotypes using biplot analysis. Journal of Animal and Plant Sciences, 26(3):754-765.

Kendal, E., M.S. Sayar, S. Tekdal, H. Aktaş, and M. Karaman. 2016. Assessment of the impact of ecological factors on yield and quality parameters in triticale using GGE biplot and AMMI analysis. Pakistan Journal of Botany, 48(5): 1903-1913.

Khalil, I.B., H.U. Rahman, N.U. Rehman, M. Arif, I.H. Khalil, M. Iqbal, Hidayatullah, K. Afridi, M. Sajjad, M. and Ishaq. 2011. Evaluation of maize hybrids for grain yield stability in north-west of Pakistan. Sarhad J. Agri. 27(2):213-218.

Kumar, V.C., and V. Devendra. 2010. Effect of plant age at harvest and season on the hydrocyanic acid potential of some sorghum cultivars. Indian J. Animal Nutr. 27(2):142-146. 
Mitrovic, B., D. Stanisavljevi, S. Treski, M. Stojakovic, M. Ivanovic, G. Bekavac and M. Rajkovic. 2012. Evaluation of experimental maize hybrids tested in multi-location trials using AMMI and GGE biplot analyses. Turkish J. Field Crops, 17(1):35-40

Mohammadi, R., M. Aghaee, R. Haghparast, S.S. Pourdad, M. Rostaii, Y. Ansari, A. Abdolahi and A. Amri. 2009. Association among non-parametric measures of phenotypic stability in four annual crops. Middle \& Eastern Russian J. Plant Sci. Biotech. 3(Special Issue I):2024

Motlhaodi, T., M. Geleta, T. Bryngelsson, M. Fatih, S. Chite and R. Ortiz. 2014. Genetic diversity in ex-situ conserved sorghum accessions of Botswana as estimated by: microsatellite markers," Australian J. Crop Sci. 8(1):35-43.

Mumtaz, A., D. Hussain, M. Saeed, M. Arshad, M.I. Yousaf and W. Akbar. 2017a. Association Studies of Morphological Traits in Grain Sorghum (Sorghum bicolor L.). J. Agri. Basic Sci. 2(1):37-43.

Mumtaz, A., H.A. Sadaqat, M. Saeed, M.I. Yousaf, A. Shehzad, H.G.M.D. Ahmed. 2017b. Genetic behaviour of qualitative and seed yield-related traits in Brassica rapa. Zemdirbyste Agri. 104 (20):147-156.

Mumtaz, A., D. Hussain, M. Saeed, M. Arshad and M.I. Yousaf. 2018. Estimation of genetic diversity in sorghum genotypes of Pakistan. J. Nat. Sci. Foundation Sri Lanka 46 (3): 271 280.

Munawar, M., G. Hammad and M. Shahbaz. 2013. Evaluation of maize (Zea mays L.) hybrids under different environments by GGE Biplot analysis. American-Eurasian J. Agric. Environ. Sci. 13 (9):1252-1257.

Pakistan Bureau of Statistics. 2015-16. Ministry of Finance. Government of Pakistan.

Panhwar, F. 2005. Sorghum practice in Sindh, Pakistan. Publisher, Digitalverlag, GmbH, Germany

PARC. 2017. Maize, Sorghum and Millets. Pakistan Agriculture Research Council, Islamabad, Pakistan.

Putto, W., A. Patanothai, S. Jogloy and G. Hoogenboom. 2008. Determination of mega-environments for peanut breeding using the CSM-CROPGRO-Peanut model. Crop Sci. 48:973-982.

Rakshit, S., K.N. Ganapathy, S.S. Gomashe, A. Rathore, R.B. Ghorade, M.V.N. Kumar, K. Ganesmurthy, S.K. Jain, M.Y. Kamtar, J.S. Sachan, S.S. Ambekar, B.R. Ranwa, D.G. Kanawade, M. Balusamy, D. Kadam, A. Sarkar, V.A. Tonapi and J.V. Patil. 2012. GGE biplot analysis to evaluate genotype, environment and their interactions in sorghum multi-location data. Euphytica 185:465-479.
Rao, P.S., P.S. Reddy, A. Ratore, B.V.S. Reddy and S. Panwar. 2011. Application GGE biplot and AMMI model to evaluate sweet sorghum (Sorghum bicolor) hybrids for genotype 9 environment interaction and seasonal adaptation. Indian J. Agric. Sci. 81:438-444.

Ritter, K.B., C.L. McIntyre, I.D. Godwin, D.R. Jordan and S.C. Chapman. 2007. An assessment of the genetic relationship between sweet and grain sorghums, within Sorghum bicolor ssp. bicolor (L.) Moench, using AFLP markers. Euphytica 157 (1-2):161-176.

Sabaghnia N., H. Dehghani and S.H. Sabaghpour. 2008. Graphic analysis of $\mathrm{G} \times \mathrm{E}$ Genotype by environment interaction for lentil yield in Iran. Agron. J. 100:760-764.

Sabaghnia, N., H. Dehghani and S.H. Sabaghpour. 2008. Graphic analysis of genotype by environment interaction for lentil yield in Iran. Agron. J. 100:760-764.

Sayar, M.S., A.E. Anlarsal, M. Başbağ. 2013. Genotypeenvironment interactions and stability analysis for dry-matter yield and seed yield in Hungarian vetch (Vicia pannonica CRANTZ.). Turk. J. Field Crops, 18(2): 238-246.

Sayar, M.S. and Y. Han. 2015. Determination of seed yield and yield components of grasspea (Lathyrus sativus L.) lines and evaluations using GGE biplot analysis method. TARIM BILIM DERG - J. Agric. Sci. 21(1): 78-92.

Selle, P.H. 2011. The protein quality of sorghum. 22nd Annual Australian Poultry Science Symposium Sydney, New South Wales14 -16th February 2011. The Poultry Research Foundation, University of Sydney, Australia.

USDA. 2017. United State department of agriculture, New York. https://www.usda.gov/.

Westcoff, B. 1987. A method of analysis of the yield stability of crops. J. Agric. Sci. 108:267-274.

Yan, W. 2001. $\mathrm{G} \times \mathrm{E}$ biplot- a windows application for graphical analysis of multi-environment trial data and other types of two-way data. Agron. J. 93:1111-1118.

Yan, W. and M.S. Kang. 2003. $\mathrm{G} \times \mathrm{E}$ biplot analysis: a graphical tool for breeders, geneticists, and agronomists. CRC Press.

Yan, W., J.F. Reid, D. Pageau, R. Martin, J. Mitchell-Fetch, M. Etieenne, J. Rowsell, P. Scott, M. Price and B.D. Hann, A. Cummiskey, J. Lajeunesse, J. Durand and E. Sparry. 2010. Identifying essential test location for oat breeding in eastern Canada. Crop Sci. 50:504-515.

Yan, W., and N.A. Tinker. 2006. Biplot analysis of multienvironment trial data: principles and applications. Canadian J. Plant Sci. 86:623-645.

Yang, R.C., J. Crossa, P.L. Cornelius and J. Burgueno. 2009. Biplot analysis of genotype 9 environment interaction: proceed with caution. Crop Sci. 49:1564-1576. 